\title{
TEKNOLOGI PENGOLAHAN AIR MINUM DARI AIR BAKU YANG MENGANDUNG KESADAHAN TINGGI
}

\author{
Oleh : \\ Wahyu Widayat \\ Pusat Teknologi Lingkungan, BPPT.
}

\begin{abstract}
Water is very important need for our live. The lack of water, in term of quqnitity quality would triger serious social \& health problems. The requirements for qualified water including element of phisical, chemical \& bacteriological. One of chemical parameter in wateris the amount of $\mathrm{Ca}+2 \& \mathrm{Mg}+2$, namely of hardnes. Since it is harmfull for human health hardness both in industrial and household consumption should be avoided. To cope the problem, there is an exact solution by processing the water with ion exchange filtration. The instalation could be used to process the water from deep well \& ordinary well on the lime mountains which generally has a high hardness into qualified drinkable water.
\end{abstract}

Kata Kunci : Air minum, Kapur, Kesadahan, Pengolahan, Penukar ion.

\section{PENDAHULUAN}

Air merupakan merupakan kebutuhan pokok bagi kehidupan manusia, sehingga jika kebutuhan air tersebut baik dalam segi kuantitas maupun kualitas belum tercukupi dapat memberikan dampak yang besar terhadap kerawanan kesehatan maupun sosial.

Pembangunan sarana dan prasarana air minum di satu sisi memberikan dampak positif bagi peningkatan cakupan pelayanan, namun di sisi lain mencerminkan ketidakefisienan investasi karena masyarakat pengguna tidak dapat memanfaatkan sebagai air minum walaupun disai sarana dan prasarananya telah memenuhi persyaratan sebagai air minum. Dari sisi kuantitas pelayanan, lingkup pembangunan air minum masih sangat terbatas, selain itu cakupan pelayanan juga masih terbatas sehingga tidak mampu mengimbangi laju kebutuhan akibat pertambahan jumlah penduduk. Hingga saat ini diperkirakan masih terdapat 100 juta penduduk Indonesia yang belum memiliki kemudahan terhadap pelayanan air minum yang memadai (WASPOLA, Bappeda 2003). Sebagian besar masyarakat yang tidak memiliki kemudahan pelayanan air minum tersebut adalah masyarakat miskin dan masyarakat yang bertempat tinggal di kawasan pedesaan termasuk di dalamya masyarakat yang tinggal daerah pegunungan kapur. Pelayanan air bersih, untuk skala yang besar masih terpusat di daerah perkotaan, dan dikelola oleh Perusahan Air Minum (PAM) kota yang bersangkutan. Namun demikian secara nasional jumlahnya masih belum mencukupi dan dapat dikatakan relatif kecil. Untuk daerah yang belum mendapatkan pelayanan air bersih dari PAM umumnya mereka menggunakan air tanah (sumur), air sungai, air hujan, air sumber (mata air) dan lainnya.

Beberapa prasarana dan sarana air minum yang sudah terbangun tidak dapat berfungsi secara optimal, salah satu penyebabnya adalah tidak dilibatkannya masyarakat setempat, baik itu pada awal perencanaan, kebutuhan, kontruksi ataupun pada kegiatan teknis, operasional dan pemeliharaannya. Hal yang lebih penting adalah pemilihan dan penentuan teknologi yang dipakai mempersulit dan susah dipahami masyarakat untuk dapat menentukan sarana dan prasarana air minum yang akan dibangun, digunakan dan dimanfaatkan pada daerah tersebut sesuai dengan kebutuhan, budaya (kultur) setempat, kemampuan masyarakat untuk mengelola sarana dan prasarana air minum tersebut. Dengan kurangnya keterlibatan masyarakat juga akan menjadikan pelayanan prasarana dan saranaair minum yang terbangun menjadi tidak berkelanjutan, tidak berfungsi dengan baik dan akhirnya tidak ada perhatian masyarakat untuk menjaga keberlanjutan pelayanan prasarana dan saran air minum tersebut. Hal yang lebih serius akan mengakibatkan prasarana dan sarana tersebut tidak memberikan manfaat bagi masyarakatpengguna secara berkelanjutan.

\section{PERMASALAHAN}

Sering dijumpai kualitas air tanah maupun air sungai yang digunakan masyarakat kurang memenuhi syarat sebagai air minum yang sehat bahkan di beberapa tempat tidak layak diminum. Air yang layak diminum, mempunyai standar persyaratan tertentu yakni persyaratan fisik, kimiawi dan bakteriologis, dan syarat tersebut 
merupakan satu kesatuan, sehingga apabila ada satu saja parameter yang tidak memenuhi syarat maka air tesebut tidak layak diminum. Pemakaian air minum yang tidak memenuhi standar kualitas tersebut dapat menimbulkan gangguan kesehatan, baik secara langsung dan maupun tidak langsung dan secara cepat atau perlahan. Salah satu parameter kimia dalam persyaratan kualitas air adalah jumlah kandungan unsur $\mathrm{Ca}^{2+}$ dan $\mathrm{Mg}^{2+}$ dalam air yang keberadaannya biasa disebut kesadahan air. Kesadahan dalam air sangat tidak dikehendaki baik untuk penggunaan rumah tangga maupun untuk penggunaan industri

Masyarakat yang tinggal di daerah berkapur atau daerah pegunungan kapur mengkonsumsi air permukaan tersebut dengan kandungan kesadahan yang tinggi. Untuk mengatasi permasalahan tersebut masyarakat setempat mengolah sendiri dengan filter sederhana dan hasilnya di masak mendidih lebih lama untuk mengurangi tingkat kesadahan.

\section{KESADAHAN}

Kesadahan merupakan istilah yang digunakan pada air yang mengandung kation penyebab kesadahan dalam jumlah yang tinggi. Pada umumnya kesadahan disebabkan oleh adanya logam-logam atau kation-kation yang bervalensi 2, seperti $\mathrm{Fe}, \mathrm{Sr}, \mathrm{Mn}$, Ca dan $\mathrm{Mg}$, tetapi penyebab utama dari kesadahan adalah kalsium ( $\mathrm{Ca})$ dan magnesium (Mg). Kalsium dalam air mempunyai kemungkinan bersenyawa dengan bikarbonat, sulfat, khlorida dan nitrat, sementara itu magnesium terdapat dalam air kemungkinan bersenyawa dengan bikarbonat, sulfat dan khlorida.

Tingkat kesadahan di berbagai tempat perairan sangat berbeda-beda, pada umumnya air tanah mempunyai tingkat kesadahan lebih tinggi dari pada air permukaan. Terbentuknya senyawa penyebab kesadahan dalam air, karena air tanah mengalami kontak dengan batuan kapur yang ada pada lapisan tanah yang dilalui air. Air permukaan lebih lunak dari pada air tanah, kesadahan non karbonat dalam air permukaan bersumber dari calsium sulfat yang terdapat dalam tanah liat dan endapan lainnya. Tingkat kesadahan air biasanya digolongkan seperti ditunjukkan pada tabel berikut ini.

Tabel 1 : Klasifikasi Tingkat Kesadahan

\begin{tabular}{|r|l|}
\hline $\mathrm{Mg} / \mathrm{Ca} \mathrm{CO}$ & \multicolumn{1}{c|}{ Tingkat Kesadahan } \\
\hline $0-75$ & Lunak (soft) \\
$75-150$ & Sedang (moderately hard) \\
$150-300$ & Tinggi (hard) \\
$>300$ & Tinggi sekali (very hard) \\
\hline
\end{tabular}

Brault, J.L, 1991
Tingkat kesadahan yang tinggi apabila dikonsumsi sebagai air minum dapat menggangu kesehatan dan menimbulkan endapan atau pengerakan dalam perkakas rumah tangga, seperti ketel, peralatan lain yang berhubungan dengan pemasakan dan penyimpanan air, sedangkan untuk keperluan lain seperti pencucian baju atau keperluan rumah tangga lain akan mengakibatkan konsumsi sabun lebih banyak, karena sabun jadi kurang efektif akibat salah satu bagian dari molekul sabun diikat oleh unsur $\mathrm{Ca}$ atau $\mathrm{Mg}$. Bagi air industri unsur $\mathrm{Ca}$ dapat menyebabkan pengerakan atau yang disebut dengan scaling pada dinding peralatan sistem penukar panas (heat exchanger) sehingga efisiensi alat penukar panas berkurang sehingga akan terjadi over heat yang mengakibatkan kerusakan pada peralatan industri. Akibat adanya masalah ini, persyaratan kesadahan pada air industri sangat diperhatikan. Pada umumnya jumlah kesadahan dalam air industri harus nol, berarti unsur $\mathrm{Ca}$ dan $\mathrm{Mg}$ dihilangkan sama sekali. Sebagai rujukan, nilai ambang batas kesadahan $\mathrm{CaCO} 3$ dapat dilihat dalam lampiran I tentang Keputusan Menteri Kesehatan RI No. 907/MENKES/SK/VII/2002 Tanggal 29 Juli 2002 Tentang Syarat-syrat \& Pengawasan Kualitas Air Minum.

Air permukaan dan tanah biasanya juga mengandung zat besi (Fe) dan Mangan (Mn) cukup besar. Adanya kandungan $\mathrm{Fe}$ dan $\mathrm{Mn}$ dalam air menyebabkan warna air tersebut berubah menjadi kuning-coklat setelah beberapa saat kontak dengan udara. Disamping dapat mengganggu kesehatan juga menimbulkan bau yang kurang enak serta meninggalkan bekas warna kuning kecoklatan pada dinding bak serta bercak-bercak kuning pada pakaian. Oleh karena itu menurut Kepmenkes No. 907/MENKES/SK/VII/2002 tersebut, kadar (Fe) dalam air minum maksimum yang dibolehkan adalah 0,3 mg/lt, dan kadar Mangan (Mn) dalam air minum yang dibolehkan adalah $0,1 \mathrm{mg} / \mathrm{lt}$ dan total kesadahan $500 \mathrm{mg} / \mathrm{l}$.

Klasifikasi kesadahan air dapat dibedakan atas 2 jenis (Fair, G.M, 1971), yaitu kesadahan sementara (temporer) dan kesadahan tetap (permanen). Kesadahan sementara disebabkan oleh garam-garam karbonat $\left(\mathrm{CO}_{3}^{2-}\right)$ dan bikarbonat $\left(\mathrm{HCO}_{3}{ }^{-}\right)$dari kalsium dan magnesium. Kesadahan karbonat merupakan bagian dari kesadahan total yang ekivalent dengan alkalinitas yang disebabkan oleh $\left(\mathrm{CO}_{3}{ }^{2-}\right)$ dan $\left(\mathrm{HCO}_{3}{ }^{-}\right)$. Kesadahan ini dapat dihilangkan dengan cara pemanasan atau dengan pembubuhan kapur tohor. Kesadahan tetap disebabkan oleh adanya garam-garam khlorida $(\mathrm{Cl})$ dan sulfat $\left(\mathrm{SO}_{4}{ }^{2-}\right)$ dari kalsium dan magnesium. Kesadahan ini disebut juga kesadahan non karbonat yang tidak dapat 
dihilangkan dengan cara pemanasan, tetapi dapat dihilangkan dengan cara pertukaran ion (ion exchange).

\section{PROSES PENGOLAHAN}

Proses pengolahan air yang mengandung kesadahan menjadi air minum dapat dilihat pada Gambar 1. Air baku yang akan diolah diambil dari sumur atau air permuakaan yang biasanya untuk daerah yang berkapur terdapat sumber air permukaan (danau) dipompa dengan menggunakan pompa bertekanan antara 4-5 bar. Untuk menghilangkan kandungan Besi dan Mangan serta logam-logam valensi dua dilakukan injeksi dengan larutan kaporit atau kalium permanganat yang berfungsi sebagai oksidator. Untuk menjamin terjadinya reaksi oksidasi air baku selanjutnya dialirkan ke tangki reaktor oksidasi yang sebelumnya melewati pencampur statis (static mixer).

Oksida besi atau oksida mangan serta oksida logam valensi dua lainnya yang terbentuk di dalam tangki reaktor oksidasi sebagian akan mengendap dan sebagian yang tidak terendapkan disaring di filter multi media. zat besi dan mangan yang tersisa tidak teroksidasi. Untuk menghilangkan polutan mikro misalnya zat organik, deterjen, bau, senyawa phenol, logam berat dan lain-lain, air yang telah diolah melalui filter multi media selanjutnya dialirkan ke filter karbon aktif. Sampai tahap proses tersebut kesadahan belum dihilangkan. Penghilangan kesadahan dilakukan dengan cara mengalirkan air ke filter penukar ion. Setelah melalui penukar ion air dialirkan ke filter cartrige ukuran 0,5 mikron untuk menghilangkan sisa partikel padatan yang ada di dalam air, sehingga air menjadi benar-benar jernih.

Tahapan selanjutnya untuk memroses air tersebut menjadi air minum yang memenuhi persyaratan sebagai air minum air dialirkan ke sterilisator ultra violet untuk menjamin air produk bebas dari bakteri dan mikroorganisme.

\subsection{Oksidasi Dengan Kaporit}

Injeksi larutan kaporit bertujuan untuk mengoksidasi zat besi atau mangan yang ada di dalam air, selain itu juga berfungsi untuk membunuh kuman atau bakteri coli. Reaksi oksidasi besi atau mangan oleh khlorine atau kaporit adalah sebagai berikut :

$$
\begin{aligned}
& 2 \mathrm{Fe}^{2+}+\mathrm{Cl}_{2}+6 \mathrm{H}_{2} \mathrm{O} \rightarrow 2 \mathrm{Fe}(\mathrm{OH})_{3}+2 \mathrm{Cl}+6 \mathrm{H}^{+} \\
& \mathrm{Mn}^{2+}+\mathrm{Cl}_{2}+2 \mathrm{H}_{2} \mathrm{O} \rightarrow \mathrm{MnO}_{2}+2 \mathrm{Cl}^{-}+4 \mathrm{H}^{+}
\end{aligned}
$$

Khlorine, $\mathrm{Cl}_{2}$ dan ion hipokhlorit, $(\mathrm{OCl})^{-}$adalah merupakan bahan oksidator yang kuat sehingga meskipun pada kondisi $\mathrm{pH}$ rendah dan oksigen terlarut sedikit, namun proses oksidasi dapat berlangsung dengan cepat. Reaksi diatas menunjukkan, bahwa untuk mengoksidasi $1 \mathrm{mg} / \mathrm{l}$ zat besi dibutuhkan $0,64 \mathrm{mg} / \mathrm{l}$ khlorine dan setiap $1 \mathrm{mg} / \mathrm{l}$ mangan dibutuhkan $1,29 \mathrm{mg} / \mathrm{l}$ khlorine. Pada kenyataanya, pemakaian khlorine ini lebih besar dari kebutuhan teoritis, hal ini disebabkan karena adanya reaksi-reaksi samping yang mengikutinya serta dipengaruhi dari kemurnian bahan oksidator itu sendiri.

Skema injeksi bahan oksidator khlorine atau kalium permanganat dapat dilihat seperti pada Gambar 2, sedangkan unit peralatannya dapat pada Gambar 3.

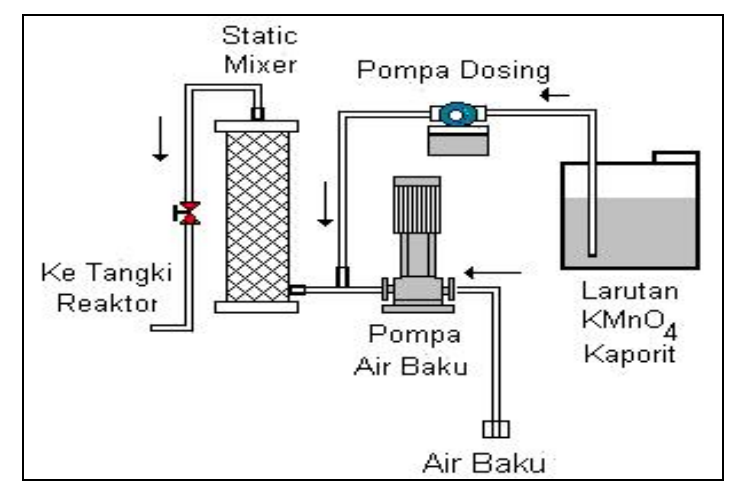

Gambar 2 : Skema Injeksi Larutan Oksidator

Pompa dosing sangat diperlukan dalam proses ini untuk menjamin akurasi dosis oksidator. Kebutuhan bahan oksidator tersebut relatif sedikit sehingga dapat dipilih pompa dosing dengan kapasitas maksimun sekitar 4,7 liter per jam. Dosis disesuaikan dengan laju injeksi yang diatur dengan cara menyesuaikan jumlah stroke yang ada pada pompa dosing. Pengadukan atau pencampuran cepat dilakukan di dalam static mixer dengan aliran cross flow (Gambar 4) dan pengadukan lambat serta proses oksidasi berlangsung di dalam reaktor oksidasi (Gambar 3).

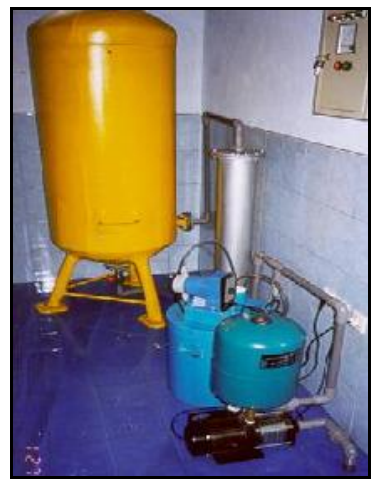

Gambar 3 : Pompa air Baku, Pompa Dosing, Static Mixer Dan Reaktor Oksidasi 


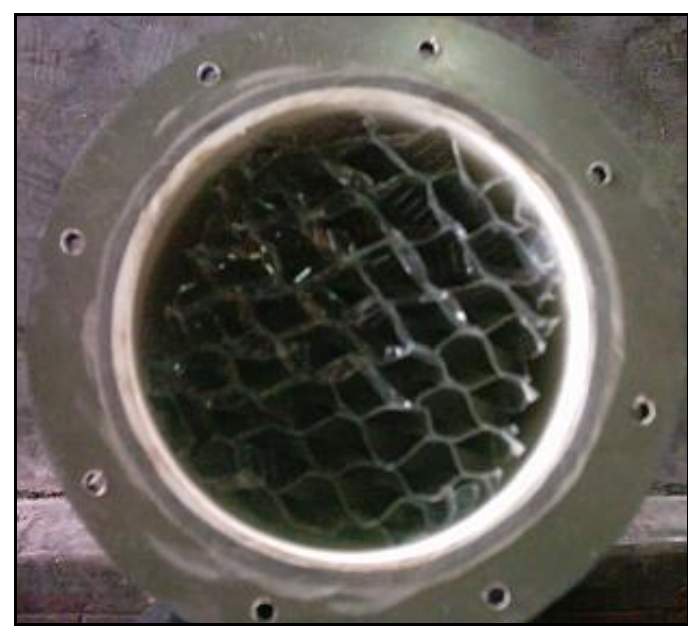

Gambar 4 : Static Mixer (Cross Flow)

\subsection{Flter Multi Media}

Setelah proses oksidasi pada tangki reaktor air dialirkan ke filter multi media yang diisi dengan pasir silika dan mangan zeolit. Pasir silika berfungsi untuk untuk menyaring padatan yang ada di dalam air serta oksida besi atau oksida mangan yang terbentuk di dalam tangki reaktor oksidasi, sedangkan mangan zeolit zeolit berfungsi menghilangkan zat besi atau mangan yang belum sempat teroksidasi oleh khlorine atau kaporit. Mangan zeolit juga berfungsi sebagai katalis dan pada waktu yang bersamaan besi dan mangan yang ada dalam air teroksidasi menjadi bentuk ferri-oksida dan mangandioksida yang tak larut dalam air.

Reaksi :

$$
\begin{gathered}
\mathrm{K}_{2} \mathrm{Z} \cdot \mathrm{MnO} \cdot \mathrm{Mn}_{2} \mathrm{O}_{7}+4 \mathrm{Fe}\left(\mathrm{HCO}_{3}\right)_{2} \rightarrow \mathrm{K}_{2} \mathrm{Z}+ \\
3 \mathrm{MnO}_{2}+2 \mathrm{Fe}_{2} \mathrm{O}_{3}+8 \mathrm{CO}_{2}+4 \mathrm{H}_{2} \mathrm{O} \\
\mathrm{K}_{2} \mathrm{Z} \cdot \mathrm{MnO} \cdot \mathrm{Mn}_{2} \mathrm{O}_{7}+2 \mathrm{Mn}\left(\mathrm{HCO}_{3}\right)_{2} \rightarrow \mathrm{K}_{2} \mathrm{Z}+ \\
5 \mathrm{MnO}_{2}+4 \mathrm{CO}_{2}+2 \mathrm{H}_{2} \mathrm{O}
\end{gathered}
$$

Reaksi penghilangan besi dan mangan dengan mangan zeoilte tidak sama dengan proses pertukaran ion, tetapi merupakan reaksi dari $\mathrm{Fe}^{2+}$ dan $\mathrm{Mn}^{2+}$ dengan oksida mangan tinggi (higher mangan oxide). Filtrat yang terjadi mengandung ferri-oksida dan mangan-dioksida yang tak larut dalam air dan dapat dipisahkan dengan pengendapan dan penyaringan. Selama proses berlangsung kemampunan reaksinya makin lama makin berkurang dan akhirnya menjadi jenuh. Untuk regenerasinya dapat dilakukan dengan menambahkan larutan Kaliumpermanganat ke dalam mangan zeolite yang telah jenuh tersebut sehingga akan terbentuk lagi mangan zeolite $\left(\mathrm{K}_{2} \mathrm{Z} . \mathrm{MnO} \cdot \mathrm{Mn}_{2} \mathrm{O}_{7}\right)$.

Bahan media terdiri dari batu kerikil kasar, kerikil halus, pasir silika kasar, pasir silika halus dan mangan zeolit. Skema susunan media yang ada di dalam filter multi media dan cara pengoperasian ditunjukkan seperti pada Gambar 5. Susunan media dari bawah ke atas adalah sebagai berikut :
- kerikil kasar

- kerikil halus

- pasir silika kasa

- pasir silika halus

- mangan zeolit

$$
\begin{aligned}
& =5-10 \mathrm{~cm} \\
& =5-10 \mathrm{~cm} \\
& =10 \mathrm{~cm} \\
& =30 \mathrm{~cm} \\
& =40 \mathrm{~cm}
\end{aligned}
$$

\section{Gambar 5 : Sususnan Dan Cara Pengoperasian} Filter Multi Media

\subsection{Filter Karbon Aktif}

Karbon aktif merupakan bahan alam, biasanya terbuat dari arang tempurung kelapa yang telah diaktivasi menggunakan uap air bertekanan (steam) dan bahan aditif lainnya untuk meningkatkan daya adsorbsi. Karbon aktif ada dua macam yaitu karbon aktif sebuk dan karbon aktif granular. Karbon aktif yang digunakan untuk filter karbon aktif berbentuk granular dengan ukuran granular antara 2-4 mm. Filter karbon aktif ini berfungsi untuk menghilangkan polutan mikro misalnya zat organik, deterjen, bau, senyawa phenol serta untuk menyerap logam berat dan lain-lain.Filter karbon aktif biasanya dilengkapi dengan screen pada bagian atas untuk menghindari bergolaknya media karbon aktif akibat aliran air. Filter karbon aktif dirangkai setelah filter multi media. Rangkaian filter multi media dan karbon atif dapat dilihat pada Gambar 6.

Di dalam filter ini terjadi proses adsorpsi, yaitu proses penyerapan zat-zat yang akan dihilangkan oleh permukaan arang aktif. Apabila seluruh permukaan arang aktif sudah jenuh, atau sudah tidak mampu lagi menyerap maka proses penyerapan akan berhenti, dan pada saat ini arang aktif telah jenuh sehingga harus diganti dengan arang aktif yang baru. Ada metode untuk 
pengaktifan karbon aktif yang telah jenuh namun kurang efektif dan kurang efisien, karena biaya regenerasi mendekati biaya penggantian karbon aktif baru.

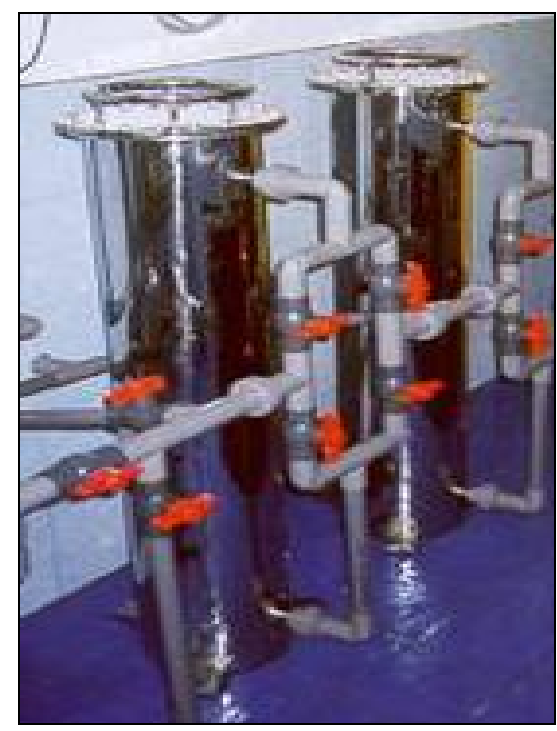

Gambar 6: Rangkaan Filter Multi Media Dan Karbon Aktif

Skema susunan media dan cara pengoperasian filter karbon aktif ditunjukkan seperti pada Gambar 7. Susunan media dari bawah ke atas adalah sebagai berikut:

- kerikil kasar

- kerikil halus

- pasir silika kasar

- pasir silika halus

- karbon aktif

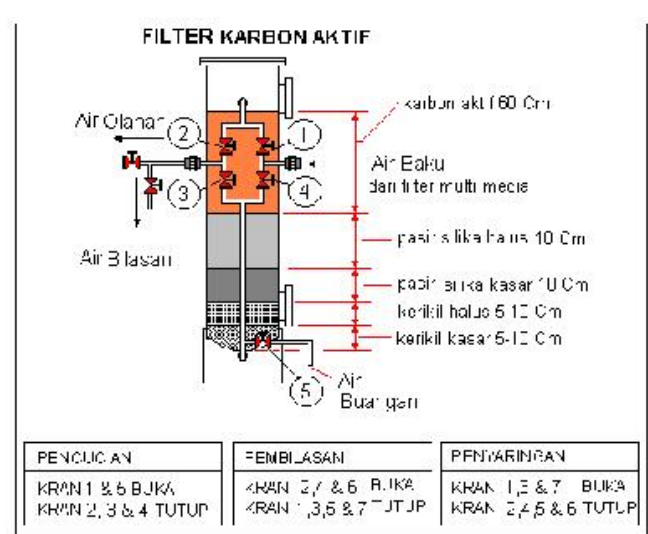

Gambar 7: Sususnan Dan Cara Pengoperasian Filter Karbon Aktif

\subsection{Filter Penukar Ion}

Di dalam filter penukar ion ini terjadi proses pertukaran ion, kalsium dan magnesium ditukar dengan sodium. Pertukaran ini berlangsung dengan cara melewatkan air baku yang mengandung kesadahan ke dalam filter penukar ion yang didalamnya terdapat unggun butiran dari bahan yang mempunyai kemampuan menukarkan ion. Bahan penukar ion pada awalnya menggunakan bahan yang berasal dari alam yaitu greensand yang biasa disebut zeolit dengan memallui proses pengaktifan. Disamping itu dapat digunakan zeolit sintetis yang terbuat dari sulphonated coals dan condentation polymer. Pada saat ini bahan-bahan tersebut sudah diganti dengan bahan yang lebih efektif yang disebut resin penukar ion. Resin penukar ion umumnya terbuat dari partikel cross-linked polystyrene. Terdapat beberapa resin penukar ion yang diproduksi oleh berbagai pabrik dan dipasaran masing-masing mempunyai nama dagang tersendiri dengan spesifikasi yang beragam.

Untuk proses penghilangan kesadahan atau pelunakan, resin yang digunakan adalah resin penukar kation yang mengandung sodium, pada proses ini ion $\mathrm{Na}$ pada resin ditukar dengan ion Ca dan Mg yang terdapat pada air yang diolah. Selama proses pelunakan, lama kelamaan ion $\mathrm{Na}$ akan habis ditukar dengan ion $\mathrm{Ca}$ dan $\mathrm{Mg}$, pada saat ini resin tersebut dikatakan telah jenuh, dan sudah tidak berfungsi lagi. Apabila resin telah jenuh maka resin tersebut perlu diregenerasi. Proses regenerasi dilakukan dengan cara melewatkan larutan garam dapur dengan konsentrasi sekitar $10 \%$ ke dalam unggun resin yang telah jenuh. Pada proses regenerasi terjadi reaksi sebaliknya yaitu kalsium dan magnesium dilepaskan dari resin, digantikan dengan sodium dari larutan garam.

Reaksi pelunakan :

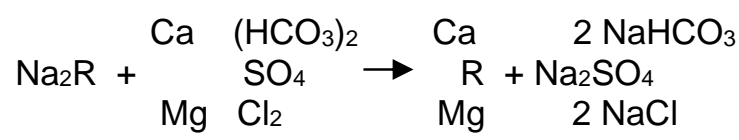

Reaksi regenerasi :

$\mathrm{Ca}$

$\mathrm{Mg}$

$\mathrm{Ca}$<smiles>[GeH3]</smiles>

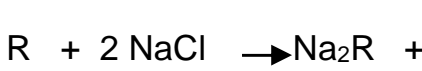
$\mathrm{Mg}$

Susunan media di dalam filter penukar ion (softener) adalah sebagai berikut :

$>$ Lapisan kerikil kasar

$5-10 \mathrm{~cm}$

$>$ Lapisan kerikil halus

$5-10 \mathrm{~cm}$

- Lapisan pasir silika kasar

$10 \mathrm{~cm}$

$>$ Lapisan pasir silika halus : $10 \mathrm{~cm}$

$>$ Lapisan resin penukar ion : $80-100 \mathrm{~cm}$

Skema dan gambar susunan media, cara pengoperasian dan regenerasi filter penukar ion ditunjukkan seperti pada Gambar 8 dan 9. 


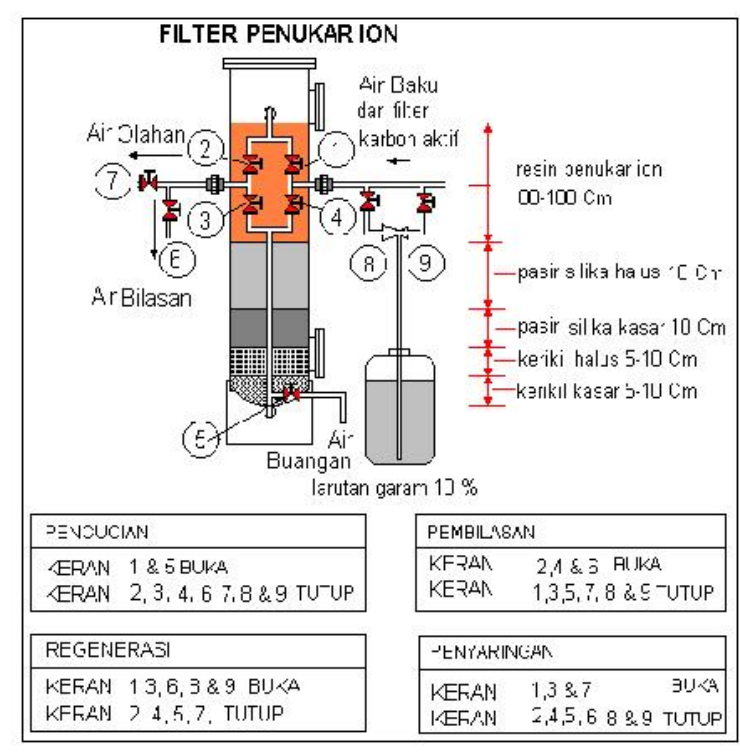

Gambar 8 : Skema Susunan Media, PengoPerasian Dan Regenerasi Filter Penukar Ion

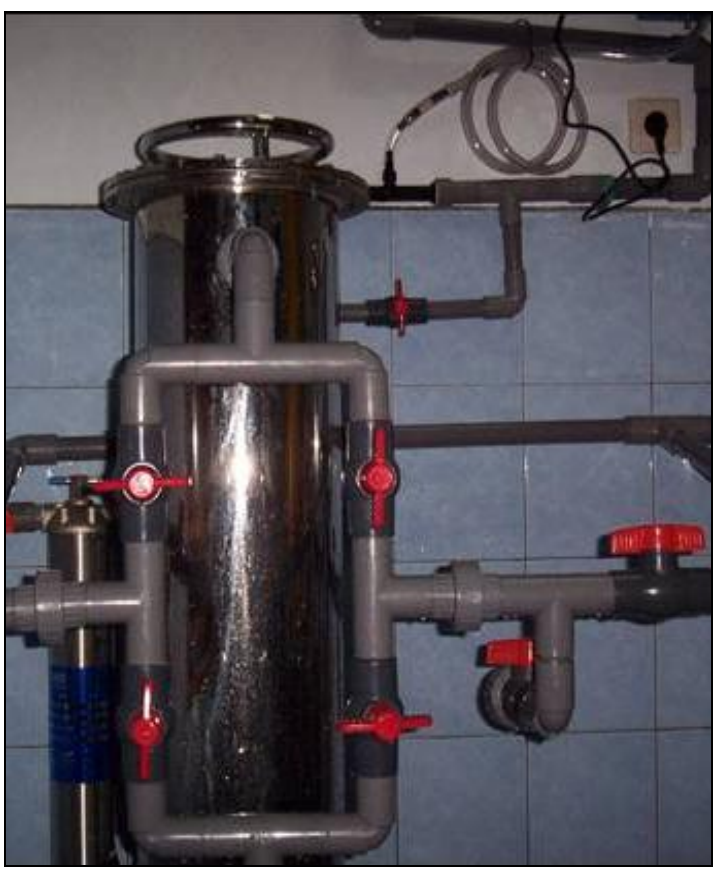

Gambar 9 : Filter Penukar lon \& Unit Regenerasi

Pada saat setelah beberapa lama pemakaian (tergantung besarnya nilai kesadahan) akan terjadi kejenuhan, sehingga diperlukan perlakuan regenerasi. Regenerasi resin penukar ion dilakukan dengan melewatkan atau mengkontakkan larutan garam dapur (10\%) ke dalam filter penukar ion. Larutan garam dapur dibuat dengan cara memasukkan $5 \mathrm{~kg}$ garam dapur ke dalam tangki garam dan dilarut kan dengan 50 liter air, lalu diaduk sampai larut. Dengan melakukan tahapan proses regenerasi seperti pada Gambar 8, maka injektor akan terjadi vakum dan akan menghisap larutan garam ayang ada di dalam tangki garam dan masuk ke dalam filter penukar ion. Proses regenerasi ini juga dapat memakai bantuan pompa dan proses regenerasi dilakukan kira-kira 15 menit. Pada beberapa plant regenerasi ini sudah menggunakan otomatisasi dengan interval waktu tertentu yang telah diatur sesuai dengan kebutuhan berdasarkan hasil analisa kualitas air baku, semakin tinggi nilai kesadahan semakin pendek interval waktu untuk melakukan regenerasi.

\subsection{Cartridge Filter}

Filter cartridge (Gambar 10) ini dapat menyaring padatan atau kekeruhan sampai ukuran 1 mikron. Dengan demikian air yang keluar dari cartridge filter ini sudah sangat jernih. Air baku yang telah melewati proses oksidasi, penyaringan di filter multi media, penyaringan di filter karbon aktif dan penyaringan di filter penukar ion, kemungkinan masih membawa kekeruhan yang berasal dari media itu sendiri, sehingga diperlukan filter dengan sekala mikro yaitu cartridge filter. Saat ini terdapat berbagai macam jenis pilihan pengolahan lanjutan setelah melakukan filtrasi dengan cartridge filter, diantaranya yaitu unit ultra filtrasi dan unit reverse osmosis, atau langsung menggunakan ultraviolet sebagai desinfeksi sehingga air hasil olahan sudah layak untuk diminum.

Apabila cartridge filter telah kotor ditandai dengan bercak kotoran pada cartridge dan tekanan pompa naik, catridge filter segera diganti dengan yang baru. Penggantian catridge filter untuk masing-masing plant berbeda-beda, namun rata-rata pemakaian diganti dalam interval waktu 3 bulan.

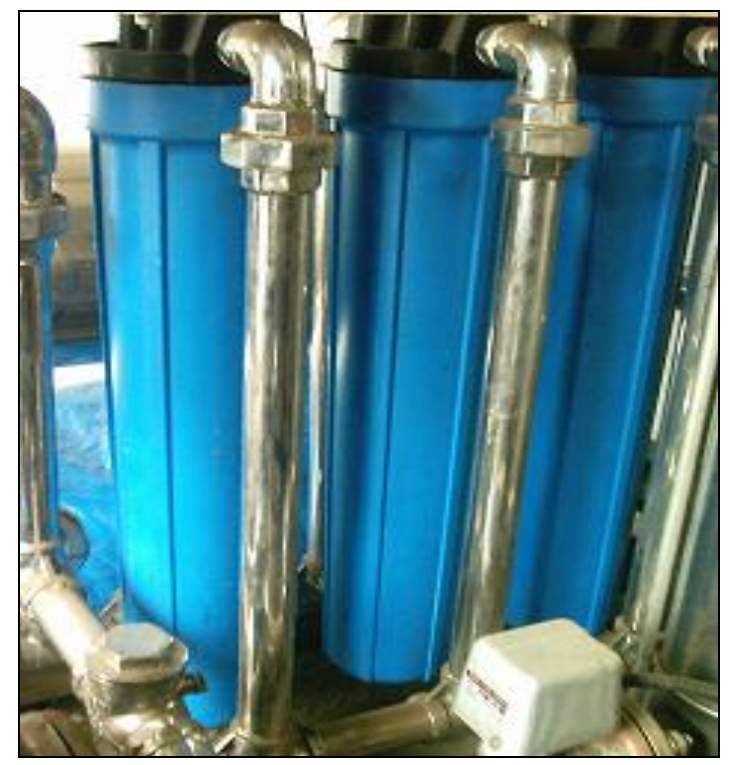

Gambar 10 : Cartridge Filter 


\subsection{Sterilisator Ultra Violet}

Air yang telah melewati cartridge filter, selanjutnya air dialirkan ke sterilisator ultra violet agar seluruh bakteri atau mikroorganisme yang ada di dalam air dapat dibunuh secara sempurna. Pengolahan air dengan ultraviolet menggunakan sinar ultraviolet yang diperoeh dari sinar ultraviolet. Lampu sinar ultraviolet sesuai dengan petunjuk produsennya memerlukan penggantian setelah pemakaian 2000 jam. Air yang keluar dari sterilsator ultra violet merupakan air hasil olahan yang dapat langsung diminum. Rangkain ultraviolet dapat dilihat pada gambar 10 .

\section{PERAN AKTIF MASYARAKAT}

Mengingat pemberdayaan masyarakat merupakan alat untuk mencapai tujuan pembangunan pengolahan air maka perubahan perilaku masyarakat menuju budaya yang lebih sehat serta mendukung keberlanjutan pelayanan air minum merupakan tolok ukur keberhasilan pembangunan air minum. Penggunaan dan pemanfaatan prasarana air minum akan lebih efektif apabila prasarana dan sarana yang dibangun ini mudah dioperasikan, mudah dipelihara, memenuhi prinsip kesetaraan yaitu dapat bermanfaat bagi setiap anggota masyarakat. Untuk prasarana dan sarana instalasi pengolahan air minum ini harus menggunakan material dan bahan yang dikenal dengan bai oleh masyarakat dan diperlukan upaya untuk melibatkan masyarakat secara aktif dalam setiap tahapan pembangunan instalasi air minum ini.

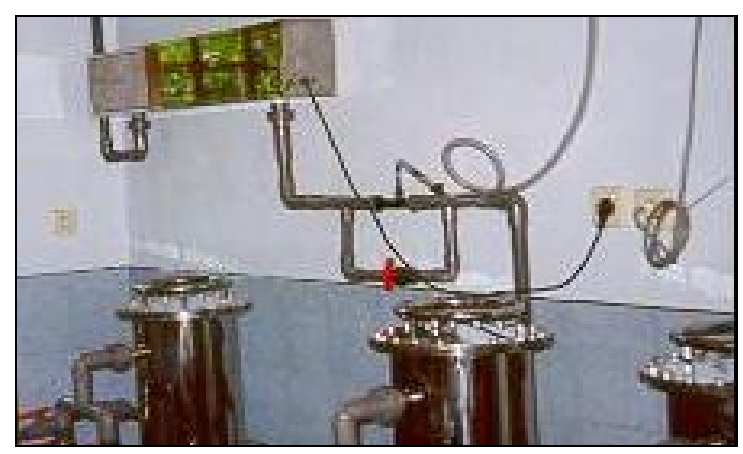

Gambar 11: Ultra violet

Untuk menunjang keberhasilan atau bergulirnya kegiatan instalasi pengolahan air ini perlunya dibekali pemahaman dan pengetahuan tentang disain peralatan dengan cara memberi pelatihan teknis, yang akhirnya dituangkan dalam spesifikasi peralatan yang akrab dengan masyarakat. Salah satu contohnya adalah penentuan teknologi dan kapasitas pengolahan air. Teknologi pengolahan air di daerah

pegunungan mengandung kesadahan yang tinggi dengan peningkatan pemahaman melalui pelatihan masyarakat diajak untuk berperan menentukan teknologi yang akan dipakai selanjutnya dalam penentuan kapasitas peralatan ini dirancang sesuai dengan kapasitas pompa yang biasa dipakai rumah yaitu 26 liter/menit atau setara dengan 12.000 liter/hari apabila dalam satu hari beroperasi 8 jam dan yang lebih penting unit peralatan secara keseluruhan dapat dengan mudah diperoleh oleh masyarakat serta kualitas air hasil olahan memenuhi persyaratan sebagai air minum, kualitas air hasil olahan dapat dilihat pada tabel:2.

\section{SPESIFIKASI PERALATAN}

Kapasitas Instalasi pengolahan air yang mengandung kesadahan menjadi air minum adalah 12.000 liter/hari dengan pengoperasian peralatan 8 jam/hari. Peralatan terdiri dari pompa air baku, pengaduk statis, pompa dosing, tangki kimia, reaktor oksidasi, filter multi media, filter karbon aktif, filter penukar ion, cartridge filter sterilisator ultraviolet. Spesifikasi masing-masing peralatan tersebut adalah sebagai berikut:

$\begin{array}{lll}\text { A. Pompa air baku } & & \\ \text { Tipe } & ; & \text { Sentrifugal } \\ \text { Power } & \vdots & 250 \text { Watt/220 V } \\ \text { Tekanan } & \vdots & 4 \text { Bars (max) } \\ \text { Kapasitas } & \vdots & 26 \mathrm{l} / \mathrm{min} \\ \text { Suction Head } & : & 9 \mathrm{~m} \\ \text { Discharge Head } & : & 40 \mathrm{~m} \\ \text { Jumlah } & : & 1 \text { unit }\end{array}$

\section{B. Pompa dosing}

Tipe

Sistem

Power

Tekanan

Kapasitas

Jumlah

Chemtech $100 / 030$
Stroke
60 watt
7 Bars
$4.7 \mathrm{lt} /$ jam
1 unit

C. Tangki Bahan Kimia

\begin{tabular}{lcl} 
Volume & $;$ & 25 liter \\
Ukuran & $:$ & $50 \mathrm{~cm} \times 25 \mathrm{~cm} \times 10$ \\
Material kontruksi & $:$ & FRP/PVC/SS \\
Kapasitas & $:$ & 50 liter \\
Kelengkapan & $:$ & Injektor \\
Jumlah & $:$ & 1 unit \\
\multicolumn{1}{l}{ D.Tangki Reaktor } & Oksidasi \\
Kapasita & $;$ & $0,5-1 \mathrm{M} 3 /$ jam \\
Ukuran & $:$ & $63 \mathrm{~cm} \times 120 \mathrm{~cm}$ \\
Material kontruksi & $:$ & FRP \\
Tekanan & $:$ & 4 Bar \\
Inlet/Outlet & $:$ & $1 "$ \\
Kelengkapan & $:$ & Static Mixer \\
Jumlah & $:$ & 1 unit
\end{tabular}




\section{E. Filter Multi media}

Tekanan
Kapasitas
Ukuran
Material
Inlet/outlet
Sistem
Media
Media penyangga
Jumlah

4 Bar

$1.4-1.8 \mathrm{~m} 3 / \mathrm{jam}$

$\varnothing 12$ inchi $x 120 \mathrm{~cm}$

FRP/PVC/SS

$1 "$

Manual

Pasir silika, manganese

Zeolit

Gravel

1 unit

\section{F. Filter karbon aktif}

Tekanan

Kapasitas

Ukuran

Material

Inlet/outlet

Sistem

Media

Media penyangga

Jumlah

\section{G. Filter penukar ion}

\section{Tekanan}

Kapasitas

Ukuran

Material

Inlet/outlet

Sistem

Media

Media penyangga

Kelengkapan

Jumlah

\section{H. Filter Cartridge}

$\begin{array}{ll}\text { Tekanan } & ; \text { 3 Bars } \\ \text { Kapasitas } & : 30 \text { Liter } / \text { menit } \\ \text { Ukuran } & : \varnothing 12 \mathrm{~cm} \times 55 \mathrm{~cm} \\ \text { Material } & : \text { Plastic } \\ \text { Inlet outlet } & : 1 " \\ \text { Jumlah } & : 2 \text { buah }\end{array}$

I. Sterilisator Ultra Violet

$\begin{array}{ll}\text { Tekanan } & ; \text { 3 Bars } \\ \text { Power } & : 120 \text { watt } \\ \text { Kapasitas } & : 30 \text { Liter } / \text { menit } \\ \text { Ukuran } & : 20 \mathrm{~cm} \times 20 \mathrm{~cm} \times 120 \mathrm{~cm} \\ \text { Jumlah } & : 1\end{array}$

\section{KESIMPULAN}

Daerah pegunungan pada umumnya mempunyai kualitas air dengan kesadahan tinggi. Salah satu cara pengolahan air dengan kondisi kualitas tersebut adalah dengan menggunbakan filter penukar ion. Pengolahan air tanah atau sumur dengan kesadahan menjadi air minum dapat dilakukan dengan proses oksidasi, penyaringan dengan filter multi media, filter karbon aktif dan filter penukar ion sebagai penghilang kesadahan, kemudian dilengkapi dengan sistem disinfeksi dengan menggunakan sterilisator ultraviolet.

Mengingat pemberdayaan masyarakat merupakan alat untuk mencapai tujuan pembangunan air minum maka perubahan perilaku masyarakat menuju budaya yang lebih sehat serta mendukung keberlanjutan pelayanan air minum merupakan tolok ukur keberhasilan pembangunan air minum. Beberapa aspek yang perlu diperhatikan untuk menuju pembangunan pengolahan air minum yang berkelanjutan adalah : aspek pembiayaan, teknologi, lingkungan, kelembagaan dan sosial

Alih teknologi dilakukan dengan peningkatan pemahaman melalui pelatihan masyarakat diajak untuk berperan menentukan teknologi yang akan dipakai selanjutnya dalam penentuan kapasitas peralatan ini dirancang sesuai dengan kapasitas pompa yang biasa dipakai rumah yaitu 26 liter/menit atau setara dengan 12.000 liter/hari apabila dalam satu hari beroperasi 8 jam dengan biaya operasional $\mathrm{Rp}$. 15,00 per liter dengan kualitas air minum (lihat tabel 3: Hasil analisa air olahan) dan yang lebih penting unit peralatan secara keseluruhan dapat dengan mudah diperoleh oleh masyarakat.

Penggunaan sarana dan prasarana air minum dikatakan efektif apabila prasarana dan sarana tersebut tepat tujuan, tepat sasaran dan dimanfaatkan oleh masyarakat dengan teknologi yang mudah dipahami, mudah dioperasikan, mudah dipelihara, mudah dimanfaatkan dan lokasi dekat dengan aktivitas sehari-hari

\section{DAFTAR PUSTAKA}

1. APHA (American Public Healt Association), " Standart Method for Examination of Water and Waste Water ", Washington DC, 1985

2. Brault, J.L."Water Treatment Hand Book", 6 th edition, Vol I, Degremont, Lavoiser Publishing, Paris, 1991.

3. Benefiled, L.D., Judkins, J.F., and Weand, B.L., "Process Chemistry For Water And Waste Treatment", Prentice-Hall, Inc., Englewood, 1982.

4. Fair, G.M., Geyer, J.C., AND Okun, D.A., " Element Of Water Supply And Waste Water Disposal ", Second Edition, John Wiley And Sons, New York, 1971.

5. Hamer, M. J., "Water And Waste water Technology ", Second Edition, John Wiley And Sons, New York, 1986.

6. Keputusan Menteri Kesehatan RI No. 907/MENKES/SK/VII/2002 Tanggal 29 Juli 2002 tentang "Syarat-Syarat dan Pengawasan Kualitas Air Minum", Menteri Kesehatan Republik Indonesia, 2002 
7. Peavy, H.S., Rowe, D.R, AND Tchobanoglous, S.G., "Environmental Engineering ", Mc Graw-Hill Book Company, Singapore, 1986.

8. Viessman W,JR., "Water Supply And Pollution Control ", fourth edition, Harper and Ror Publisher, New york, 1985.
9. WASPOLA "Kebijakan Nasional dalam Pembangunan Air Minum dan Penyehatan Lingkungan Berbasis Masyarakat", Departemen Permukiman dan Prasarana Wilayah, Bappeda, 2003

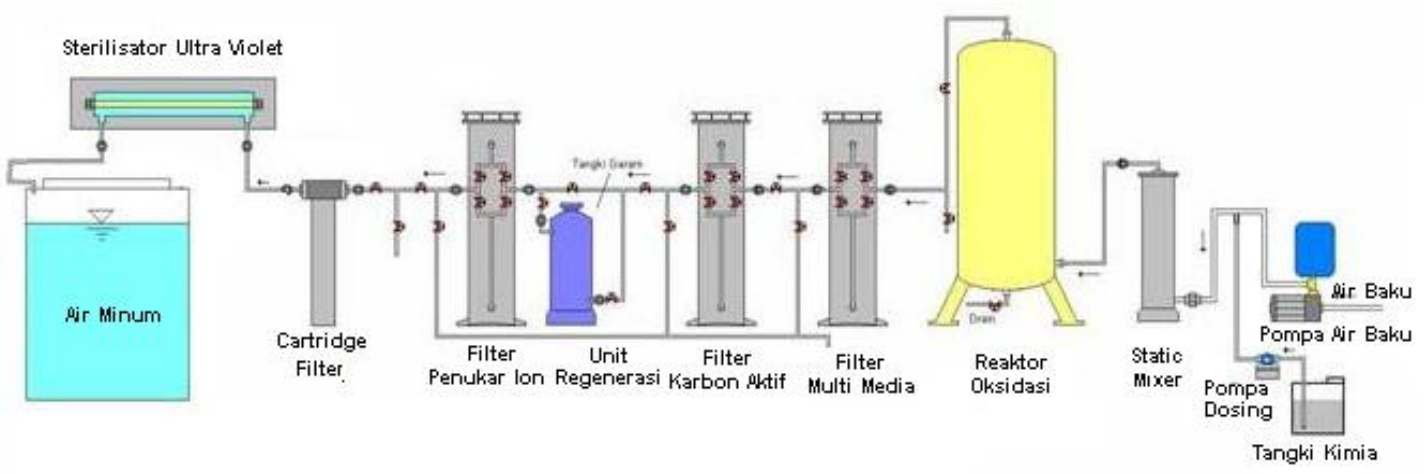

Gambar 12 : Diagram Proses Pengolahan Air Yang Mengandung Kesadahan Menjadi Air Mnum

Tabel 2 : Hasil Analisa Kualitas Air Olahan

\begin{tabular}{|c|c|c|c|c|c|}
\hline \multicolumn{2}{|c|}{ Parameter } & \multirow[t]{2}{*}{ Unit } & \multirow[t]{2}{*}{ Test Results } & \multirow[t]{2}{*}{$\begin{array}{l}\text { Requirement } \\
\text { SNI 01-3553-1996 }\end{array}$} & \multirow[t]{2}{*}{$\begin{array}{l}\text { Method*) } \\
\text { Part Number }\end{array}$} \\
\hline 1 & Organoleptic: & & & & \\
\hline & 1.1 Odor & - & Negativ & Odorless & $2150 \mathrm{~B}$ \\
\hline & 1.2 Taste & - & Normal & Tasteless & $2160 \mathrm{C}$ \\
\hline & 1.3 Color & Pt Co scale & Nil & 2.5 & $2120 \mathrm{~B}$ \\
\hline \multirow[t]{21}{*}{2} & Physical \& chemical : & & & & \\
\hline & $2.1 \mathrm{PH}$ & - & 7.57 & $6.5-8.5$ & $4500-\mathrm{H}^{+}-\mathrm{B}$ \\
\hline & 2.2 Turbidity & NTU & $\mathrm{Nil}$ & 5 & $2130 \mathrm{~B}$ \\
\hline & $\begin{array}{lll}2.3 & \text { Total Hardness as } \\
\mathrm{CaCO}_{3} & & \end{array}$ & $\mathrm{mg} / 1$ & 10.26 & 500 & $2340 \mathrm{C}$ \\
\hline & $\begin{array}{ll}2.4 & \text { Dissolved Solid }\end{array}$ & $\mathrm{mg} / 1$ & 400 & 500 & $2540 \mathrm{~B}$ \\
\hline & $\begin{array}{ll}2.5 & \text { Organic Meter by } \\
\mathrm{KmnO}_{4} & \end{array}$ & $\mathrm{mg} / 1$ & 0.96 & 1.0 & $\begin{array}{l}\text { Permanganometri } \\
\mathrm{c}\end{array}$ \\
\hline & 2.6 Nitrate & $\mathrm{mg} / 1$ & Below 0.001 & 45 & $4500-\mathrm{NO}_{3}-\mathrm{B}$ \\
\hline & 2.7 Nitrite & $\mathrm{mg} / 1$ & Below 0.001 & 0.005 & $4500-\mathrm{NO}_{2}-\mathrm{B}$ \\
\hline & 2.8 Ammonium & $\mathrm{mg} / 1$ & Below 0.04 & 0.15 & $4500-\mathrm{NH}_{3}-\mathrm{C}$ \\
\hline & 2.9 Sulfate & $\mathrm{mg} / 1$ & 7.11 & 200 & $4500-\mathrm{SO}_{4}^{2}-\mathrm{E}$ \\
\hline & 2.10 Chloride & $\mathrm{mg} / 1$ & 77.70 & 250 & $4500-\mathrm{Cl}^{-}-\mathrm{B}$ \\
\hline & 2.11 Floride & $\mathrm{mg} / 1$ & 0.16 & 1.0 & $4500-\mathrm{CF}^{-}-\mathrm{B}$ \\
\hline & 2.12 Cynide & $\mathrm{mg} / 1$ & Below 0.01 & 0.05 & $4500-\mathrm{CN}-\mathrm{B}$ \\
\hline & 2.13 Iron & $\mathrm{mg} / 1$ & Below 0.04 & 0.3 & $3500-\mathrm{Fe}-\mathrm{B}$ \\
\hline & 2.14 Manganese & $\mathrm{mg} / 1$ & Below 0.02 & 0.05 & 3500-Mn-B \\
\hline & 2.15 Free Chlorine & $\mathrm{mg} / 1$ & Below 0.02 & 0.1 & $4500-C 1_{2}$ \\
\hline & 2.16 Heavy Metal: & & & & \\
\hline & 2.16 .1 Lead & $\mathrm{mg} / 1$ & Below 0.01 & 0.05 & $3500-\mathrm{Pb}-\mathrm{B}$ \\
\hline & 2.16.2 Copper & $\mathrm{mg} / 1$ & Below 0.03 & 0.5 & $3500-\mathrm{Cu}-\mathrm{B}$ \\
\hline & 2.16.3 Cadmium & $\mathrm{mg} / 1$ & Below 0.005 & 0.01 & $3500-\mathrm{cd}-\mathrm{B}$ \\
\hline & 2.16.4 Mercury & $\mathrm{mg} / 1$ & Below 0.001 & 0.001 & $3500-\mathrm{Hg}-\mathrm{B}$ \\
\hline \multirow[t]{6}{*}{$\overline{3}$} & Bacteriological : & & & & \\
\hline & 3.1 TP (Fabric) & per $\mathrm{ml}$ & - & $1.0 \times 10^{2}$ & $9215 \mathrm{~B}$ \\
\hline & 3.2 TPC (market) & per $\mathrm{ml}$ & $8.0 \times 10^{4}$ & $10 \times 10^{5}$ & $9215 \mathrm{~B}$ \\
\hline & 3.3 Coliform & per $100 \mathrm{ml}$ & Nil & $<2$ & $9222 \mathrm{~B}$ \\
\hline & 3.4 Salmonella sp & per $100 \mathrm{ml}$ & Negative & Negative & $9260 \mathrm{D}$ \\
\hline & 3.5 Clostridium sp & per $\mathrm{ml}$ & Negative & Negative & $\left.{ }^{* \star}\right)$ \\
\hline
\end{tabular}

*) Standar Methode, $19^{\text {th }}$ Edition 1995, APHA-AWWA-WEF

**)"The testing of water" SNI 01-3554-1994 